\title{
Military Vehicles Used for Public Service Purposes ${ }^{1}$
}

\author{
György GÁVAY²
}

\begin{abstract}
The aim of the publication is to examine and present the need and possibilities of using protected vehicles in the police and disaster management forces. One of the questions arising nowadays is what threats the police and disaster management forces are facing at the locations of terror attacks or environmental catastrophes. The reduction of the tühreats is possible with choosing the appropriate vehicles and ensuring their proper usage.
\end{abstract}

Keywords: public service, terror attacks, protection requirements, MRAP vehicles

\section{Introduction}

The publication describes the connection between protected (armoured) vehicles and public service tasks, the need for using protected vehicles and their ability for protection. Its aim is to summarize the information dealing with the needs and possibilities of using protected vehicles in cases of crimes typical to the present day, as well as areas struck by a catastrophe.

The term protected vehicle mainly refers to protection against an attack, but the given ability to protect can also be used for other harmful events not caused by an attack. The aim of using a protected vehicle is to prevent and lessen the harmful events of an attack or harmful events not caused by an attack, to protect the lives and physical safety of the person(s) within the vehicle's inner space. The term protected vehicle used by the Hungarian home affairs organizations refers to vehicles carrying protected individuals.

For the clarification of harmful events the terms threat, endangerment and safety need to be investigated. The publication divides the categories threat and endangerment into two parts. One contains the threats caused intentionally, by humans, while the other contains the threats caused by natural or industrial catastrophes. It is an interesting fact that the vehicles built for avoiding the first category worked out surprisingly well with disaster management activities.

Based on the above, this publication deals with the topics of threat and safety, the used vehicle types and their design as well as ballistic protection and protection against explosion.

It is hard to pre-define the risk and intensity of an attack carried out by hostile individuals, as well as the direct and indirect effects of a natural or industrial catastrophe. All the same it is required to be prepared for the protection of personnel on duty and executing public service tasks in the given area.

Supported by the ÚNKP-17-3-3-NKE-17. New National Excellence Program of the Ministry of Human Capacities.

2 Captain, Assistant Lecturer, National University of Public Service; e-mail: gavay.gyorgy@uni-nke.hu 


\section{Protected Vehicles}

The term protected vehicle can be easily defined based on the topic of the publication. A vehicle that can move by self-effort and provides protection for those inside from intentional and unintentional harmful events. This ability to protect is always present without any help from the outside.

The military vehicles can be structured based on the aspects of protection. Ballistic protection and protection against an explosion are such aspects. It is also important to clarify that such protection capabilities can be reached in an active or passive way, in this case only the passive protection capability will be discussed.

Based on the above, a protected vehicle can be an armoured car or an armoured vehicle made for military purposes. The protected vehicle used in police terminology and mentioned in the introduction means the vehicle and the individuals within protection by the organization's own personnel.

\section{Public Service Tasks}

The literature used for the preparation of this publication, both national and foreign sources and case studies mention personnel carrying out tasks who are part of organizations that belong to national or-in case of the US-federal governance. Taking into consideration their executed tasks, those organizations that are not public service organizations still carry out rescue activities also need to be mentioned since they have a licence to operate issues based on a separate legislation.

\section{Basic Terminology of Public Service}

When defining [1] public servants or public service employees we look for individuals who can be subject to public service legal relations. To be able to identify who can be a public servant, first the word public service needs to be defined. Starting from the linguistic origins of public service, the service provided for the public can be considered the source. Not everyone can be the subject of public service, the above linguistic approach is only valid for the public sector.

The most broadly interpreted public service legal relations are in connection with the following organizations, such as:

- elected representatives of the legislative and national representation bodies (Members of Parliament and local representatives);

- personnel of the justice organizations (Court, Prosecutor’s Office);

- personnel of the public administration (public servants);

- personnel of the organizations performing public duties that are operated by the state (hospitals, schools, social institutions);

- further individuals or personnel of other organizations performing public administration tasks;

- employees of state-owned companies; 
- members of public foundations and public corporations;

- and last, but not least the personnel of armed and other law enforcement organizations (police, national defence, military, fire-brigade).

Henceforth I am going to use the term public service task execution, which refers to the work of the police, ambulance, disaster management personnel as well as the military forces involved in disaster recovery and counter-terrorism activities.

\section{Vehicle Usage in the Public Service}

Public service is defined by the executed task and the organization, since based on the terminology public duties need to be carried out at a public service body.

The publication discusses the public service tasks already mentioned in the introduction. It takes into consideration branches of public service where vehicle usage is inevitable and where the usage of protected vehicles might be required. These include law enforcement, military and disaster recovery activities, as well as related lifesaving actions. When executing military operations, there is no reasoning required for the usage of protected vehicles and most of the military industry developments target this field. The need of the law enforcement organizations for using protected vehicles is visibly growing, but other aspects of the organizations' appearance in the civilian environment also need to be taken into consideration. The effect of the presence of a military vehicle [2] at a busy location, the impact it has on the sense of security and feelings of the civilian population are important questions, but of course safety needs to come first. In a civilian environment a known military vehicle can even raise panic, in contrast to a less military-looking vehicle.

\section{Law Enforcement and Internal Security, Personal Protection}

Since the 1946 Jerusalem explosion [3] the world got to know the meaning of terrorist activities affecting the civilian population in the modern era. Since then law enforcement authorities are facing a new requirement in almost every developed and developing country, which is the need to transport their personnel safely to the location of the event to be able to secure the area. The safety of the personnel needs to be looked at together with the threat. The publication does not take a stand on the likelihood and applied equipment of any future action, but takes the offensive equipment used in past events as examples and does not exclude the threat caused by them or the usage of more powerful weapons.

The dangerous actions against which protection is needed can be outlined based on certain events of the near past, since multiple terror attacks have happened in the previous years where the perpetrators have used unusual weapons. 


\section{Police Forces, their Task Structure and Vehicle Usage}

It is hard to decide which public service organization faces the biggest danger, but the personnel of the police forces that is in direct contact with the civilian environment can be most rapidly mobilized and is of the biggest headcount. Vehicle usage is inevitable for carrying out the tasks of these organizations, and the task execution requiring vehicle usage has the biggest risk in this case taking into account the number of events.

\section{The Tasks of the Organizations that Belong to the Ministry of the Interior}

Taking a look at the below listed tasks [4] of the police it becomes clear that there is no item on the list where vehicle usage would not be needed and in most of these cases the usage of protected vehicles also seems required even for an outside observer:

- as a law enforcement investigative authority police prevents and detects crimes;

- as an authority it contributes to the prevention and detection of offenses;

- it carries out the official tasks associated with the production, distribution and usage of equipment and materials threatening public security, approves and controls the personal and property protection, as well as private detective activities;

- it carries out law enforcement, as well as traffic authority tasks associated with maintaining the order of public areas;

- it ensures the personal safety of participants of criminal procedures and the members of the authority carrying out the proceedings, protects the lives and physical integrity of individuals considered as highly important for the interests of Hungary, guards the appointed institutions;

- it executes activities related to enforcement of sentence;

- it carries out law enforcement tasks transferred to its authority in case of a state of emergency, state of preventive defence, state of disaster or disaster threat;

- it guards the state border, prevents, detects and stops any illegal crossing of the state border, it carries out the immigration control and asylum related tasks transferred to its authority as well as controls the persons and vehicle traffic crossing the state border;

- it carries out the legally defined internal crime prevention and crime detection related inspections;

- it detects the terrorist organizations operating on Hungarian territory, it prevents these organizations from committing crimes, it prevents any organization or individual from providing financial or any other support for terrorist organizations from Hungarian territory;

- it carries out further tasks declared in laws or government decrees as well as binding acts of the European Union or international contracts. It also participates in peace support and civilian crisis management activities organized by the UN, EU, OSCE (Organization for Security and Cooperation in Europe), NATO or based on international contracts. 
The specific tasks and the vehicle usage are in close connection with the task structure of the police. [5] Activities that require vehicle or protected vehicle usage will be introduced below:

"March" is the activity of the unit force that is in close connection with tactical processes, manoeuvre types and also supplements these. March is the purposeful and organized movement of the personnel with standard or augmented carrier vehicles or on foot. The bonds can execute the march individually or in march columns.

"Closure" is a general tactical process that can occur as part of personal and object protection activities, higher level inspections, safety activities or location protection, which can occur in the following cases:

- activities regarding the protection of law and order, traffic, immigration control and law enforcement;

- event protection;

- at the location of a terrorist attack or other serious crimes;

- at the location of a catastrophe or a mass-casualty incident;

- capture of an armed individual on the run, who has committed a serious crime;

- crowd dispersion as part of the activities of the protection unit.

When preparing a closure, the following needs to be taken into consideration based on the task:

- the number, armament, known and expected actions of the armed fugitives and wanted individuals;

- the size, composition, mood and intentions of the crowd present at events;

- the traffic conditions of roads and railways;

- the status of public transport;

- the available forces and assets;

- characteristics of the area;

- the season, time of the day and weather.

The strength of the closure team can be enhanced with armoured vehicles. The pit is the fireposition of the magazine-fed weapon or armoured vehicle established at the closure line, its power is constituted by the firearm and its operators.

The checkpoint is established by a unit (closure team, protection team) at a predefined location for the inspection and control of the departing person and vehicle traffic, as well as the compliance with the restrictive regulations. Upon establishing a checkpoint, the following aspects are important:

- the protection of the assigned personnel;

- the safe and secure execution of the inspection.

Among others, the assigned personnel can be supported by transportation and armoured vehicles.

At the closure line within inhabited settlements the different types of cordon devices, constructed obstacles, road blocks and vehicles need to be widely used for the strengthening of the closure. In this case it is mandatory that the vehicles are parked back-to-back or in 
V-shape occupying the whole road junction and the pavement in a way to make a quick drive away possible if required.

Taking into consideration the traffic safety, the police force can also establish a road block in the course of a traffic restriction set up in order to capture the offender. The road block is a coercive instrument for arresting and capturing individuals escaping police measures with a vehicle and it forces them to stop by installing for example vehicle(s) in a barricade form.

Vehicle usage as well as the usage of armoured or protected vehicles (terminology used in this publication) is also necessary when operating the following units:

- pursuer team;

- capture-liquidation team;

- cover-support team;

- insurance team;

- sentinels.

The aim of event insurance is to provide the conditions required for the legitimate, uninterrupted arrangement of events attracting a large crowd and to maintain the safety of persons, wealth and traffic at the event and its surrounding locations. The aim of insuring large locations is to provide the conditions required for the uninterrupted execution of damage prevention or damage control in a defined area, enforcement of closure measures, fulfilment of public safety tasks in connection with disaster recovery or other measures aimed at the protection of civilians.

\section{Counter Terrorism Centre}

The conditions of safety and national security have changed fundamentally. The most significant security threat affecting the Western world is terrorism. The law enforcement authorities need to face terrorist organizations [6] and the cooperation of groups operating at locations geographically far from each other. The Counter Terrorism Centre (in Hungarian: Terrorelhárítási Központ - TEK) is a law enforcement authority under the command of the Minister of the Interior and has jurisdiction over the whole territory of the country. Its mission is to detect and abort serious criminal offenses of terrorist nature, such as terrorism, kidnapping, capturing aircrafts, vehicles of public transportation on railway, water or road, as well as transit vehicles.

On request by the law enforcement authorities TEK is also responsible for capturing armed individuals suspected of committing a crime, as well as stopping other violent crimes against persons, and it carries out detective, preventive and law enforcement tasks, too.

\section{Organizations Responsible for Rescue Tasks (Ambulance)}

The operating environment as well as the activities carried out by the personnel of organizations responsible for rescue tasks are governed by the 5/2006. (II. 7.) EüM (Ministry of Health) regulation. [7] In case of terrorist attacks and catastrophes, the rescue options can best be determined or assessed on site or as close to the location as possible. It is obvious 
that securing the area is the responsibility of the Disaster Management and police forces and it needs to be executed as quickly as possible so that the doctors performing rescue tasks can help the injured people as soon as possible.

The paramedic officers, ambulance doctors, paramedics and drivers (referred to as ambulance) need proper attention and concentration skills to be able to act in case the alarm goes off. Their work is stressful and requires great presence of mind especially in cases of unexpected catastrophes or mass-casualty incidents.

The job itself is subject to numerous dangerous situations (life or health threatening circumstances) that can occur due to:

- traffic conditions;

- contact with people endangering themselves or the public, as well as suffering from infectious diseases;

- working environment.

Apart from the ambulance station, the ambulance staff works at different locations, where also bad road conditions or harsh weather need to be taken into consideration when visiting the injured people and the locations of the accidents. After arriving at the location, occasionally open-air work is required as well, for example in case of traffic accidents or sports events, where tasks need to be carried out while facing harsh weather conditions. For the sake of the study's topic it is more important to stress that the duties also need to be executed at dangerous locations, for example in case of fires or chemical disasters, but of course only in maximum compliance with the protective measures required by the situation (fire and acid proof equipment, oxygen mask, etc.). [8]

Having a relative sense of safety can help remarkably when carrying out the tasks at a dangerous location. Using a special vehicle can make moving at a hard-rough surface and working in a dangerous environment easier and safer.

\section{Disaster Management}

A new organizational structure was formed at the Ministry of the Interior, National Directorate General for Disaster Management (in Hungarian: BM Országos Katasztrófavédelmi Főigazgatóság - BM OKF) on 1 January 2012 together with the April organizational changes and in line with the new act on disaster management and its executive government and ministerial decrees for carrying out the outlined tasks. This stands on three pillars: industrial safety, civilian protection and fire protection. The activities of the national chief inspectorate for industrial safety established for carrying out industrial safety tasks cover four main professional areas. These are the supervision of dangerous plants, the inspection of transportation of hazardous goods, the protection of critical infrastructures and the prevention as well as recovery of nuclear accidents. [9]

When the explosion risk still exists in case of an industrial accident or catastrophe, a vehicle that can approach the area can be required in order to inspect the situation. 


\section{Applied Vehicles}

The vehicle fleet of the home affairs organizations is very diverse. It mostly consists of patrol vehicles based on regular personal vehicle types as well as other supply vehicles such as vans or minivans. Some of these can be 15-20 years old, but the average age of the vehicles is being reduced thanks to procurements. The patrol cars that make up most of the service vehicle fleet are enough for the everyday activities, but the already introduced more risky tasks require armoured vehicles.

Adapting to the conditions of the surface attributes, off road ambulance cars also exist, but there is no equipment that would provide protection from attacks. For this purpose, help from other public service authorities is or could be required.

The vehicle fleet of the Disaster Management is also diverse, ranging from off road vehicles to fire trucks.

\section{Today's Threats and the Need for Using Protected Vehicles}

In today's Europe the threat caused by terrorist attacks has increased significantly. Shootings, explosions and wilful run-over actions that aim at increasing the number of civilian victims and threatening the population happen almost every month. Capturing vehicles of public transportation or mass-transit is happening more and more often as it is rather easy and quick to implement.

These activities result in an immediate intervention from the public service side. It is hard to identify beforehand the dangers of the public service work done at these occasions. This difficulty needs to be overcome somehow, since the public service task execution can be carried out with best efficiency if the personnel involved is aware of the threats, is prepared for these and has at hand the available equipment for protection.

The situation handling after activities committed for the threatening of the civilian population can have a very strong and negative effect on the public service personnel performing duties on site. The stress management and prevention of post-traumatic behaviour of the personnel working in disaster management is highly important, since their work and service is required in the long run. The introduction and short analyses of several up-to-date examples will follow below.

\section{The Criminal Attempt Against the Editorial Office of Charlie Hebdo in Paris}

Taking account of recent violent acts, one is considered specifically brutal by the police. The editorial office of the Charlie Hebdo magazine was attacked by individuals armed with AK-47 type automatic rifles. Apart from civilian victims, a police officer on duty also died. Video recordings are available of the crime, the weapons used are visible in the pictures taken from these videos. [10] 

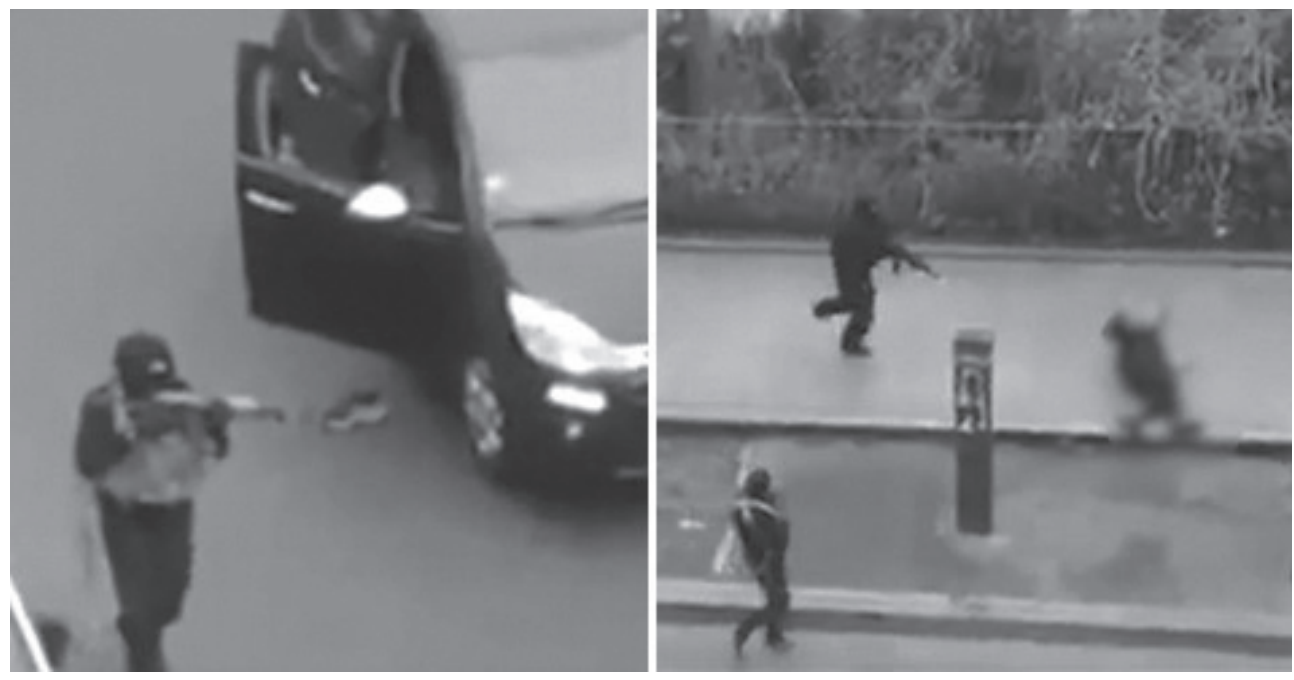

Picture 1. Terrorist attackers in Paris. [11]

The attackers did not care about the state of the injured police officer, they have executed him in a coordinated way covering each other, thus it can be stated that they would have opened fire at the arriving police forces, as well. The attackers were shot after a three-day manhunt.

Considering the weapons and ammunition used by the aggressors, they would have been able to attack an armoured vehicle with STANAG 4569 Level 2 protection capacity and this significantly increases the level of danger the arriving police forces were facing.

\section{Criminal Attempt in Norway}

Two coordinated criminal attempts hit Norway on the $22^{\text {nd }}$ of July 2011. At 3:30 p.m. local time an explosion happened in the centre of the capital, while a few hours later tragic shootings were reported from Utoya, located $10 \mathrm{~km}$ from Oslo, from a camp organized by the Norwegian Labor Party. [12]

According to reports, it took 50 minutes for the police to arrive at the location of the shooting. They were taking a car as the helicopter was not on standby, so it took them 20 minutes to get to the lake and another 20 minutes to find a boat available to reach the island located a few hundred meters from the shore. The offender was using a Glock 34 pistol and a Ruger mini rifle. [13]

The massacre was committed at a location hardly accessible, approaching the area caused problems, and even though a large explosion has already happened previously, [14] based on the available data and pictures, the authorities first arrived with patrol vehicles.

The murderer declared his surrender on the phone, claiming he has accomplished his "mission”, so he showed no sign of resistance. [15] Even if an attacker indicates giving up, this cannot be taken for granted. 
In the above example the assassin could have effectively shot at the police officers and ambulance team arriving from the other side.

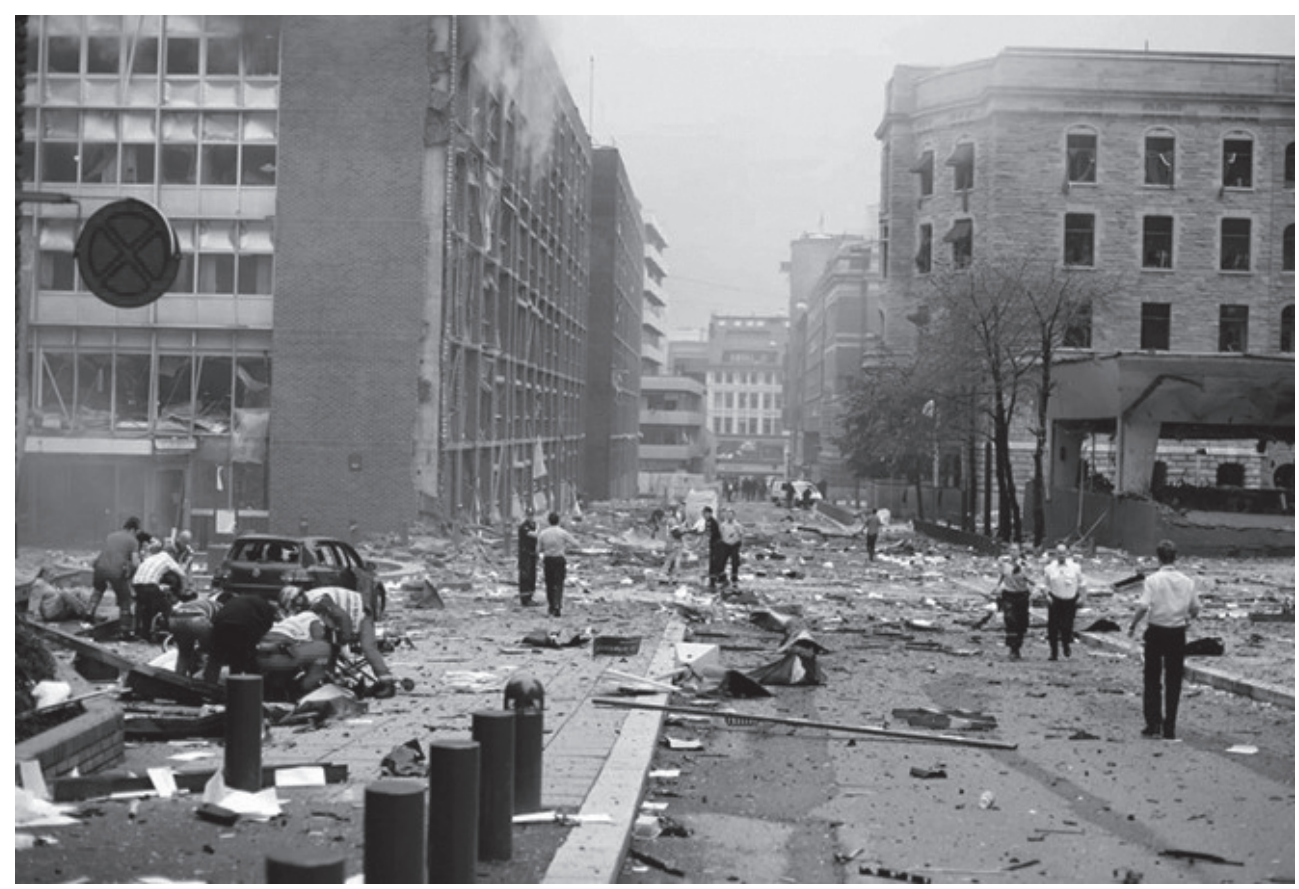

Picture 2. The scene of the explosion in Norway.

The explosion happened in the near vicinity of the main government building. [14]

The aggressor planned the double criminal attempt in detail, prepared an enormous number of explosives, and even though according to the video recordings he did not park the van carrying the explosives at the originally planned location, a significant amount of harm was caused. Along this line of thinking, if another explosion happened 20-30 minutes after the first one, it would have had fatal consequences for the ambulance and police forces that arrived at the location.

As a summary it can be stated that according to the Hungarian terminology, the personnel carrying out public service tasks (police, disaster management and ambulance teams) were approaching the crime scenes with vehicles that would have been unable to provide protection in case of another attack aimed directly at them. The attack was clearly aimed at the ministry employees, therefore against public service workers.

\section{Firearms}

All armed aggressors have carried out the attacks with firearms. One of the most widespread assault rifles, the AK-47 or one of its subtypes or successor types was used at the attacks against the editorial office of Charlie Hebdo in Paris. The assault rifle is an automatic rifle 
equipped with stock and is capable of single shots or multiple rounds. It has a medium barrel length and is using rifle rounds. One cannot be specific about the type as this weapon has numerous subtypes and one of the characteristics of asymmetric warfare is that the enemy uses any firearm that they find available. The subtypes of AK-47 differ in barrel length, calibre, stock design and further accessories. Typical rounds used:

- $7.62 \times 39 \mathrm{~mm}(\mathrm{M} 43)$;

- $7.62 \times 39 \mathrm{BZ}$ - armour piercing incendiary;

- $7.62 \times 39$ AP (hard steel or tungsten carbide core armour piercing incendiary);

- $5.45 \mathrm{~mm}(\mathrm{M} 74)$.

According to data from the early 2000s, around 80 million pieces of AK type rifles were manufactured worldwide. [16] They are sold for a few dollars at the African markets and smuggled through Western Asia to India in large quantities.

At the time of the former Yugoslav crisis a high number of weapons and ammunition vanished from abandoned munition and arms manufacturing factories as well as military bases. [17] Such equipment can reach Western Europe through smuggling. [18] The Serbian police caught a group of ten smugglers and seized $9 \mathrm{~kg}$ plastic explosives, $20 \mathrm{~kg}$ TNT, electric detonators, 111 hand grenades, 2 rocket launchers, 12 armour piercing grenades, rifles, machine guns, other weapons and ammo during the operation. The whole list contained more than 6,000 items. Firearms trafficking began to flourish at the time of the former Yugoslav crisis (1991-1995). Data from 2011 suggests that around 2.5 million households own 3 million illegal weapons.

The rifle used in Norway was a Ruger mini, the perpetrator even bought an optical sight for it. This rifle fires $5.56 \times 45 \mathrm{~mm}$ bullets and can fire well aimed and effective rounds up to a several hundred metres distance.

It is obvious that a protected vehicle capable of providing shelter from this weapon needs to be selected for the protection of the public service personnel.

\section{Capturing Vehicles of Mass-Transit}

In recent years several incidents happened that made it clear that mass-transit vehicles can easily be used for committing crimes against human life. One of these events happened in Nice, where around 10:30 p.m. during a celebratory fireworks a truck slammed through the crowd for a two kilometre distance with an approximate speed of $80 \mathrm{~km} / \mathrm{h}$ and drove in a way to hit more people, while also shooting into the crowd. According to a journalist who was present at the location and saw what happened, there was blood everywhere and many injured people. [19] [20] At least 84 victims and more than 60 injured have been reported. 


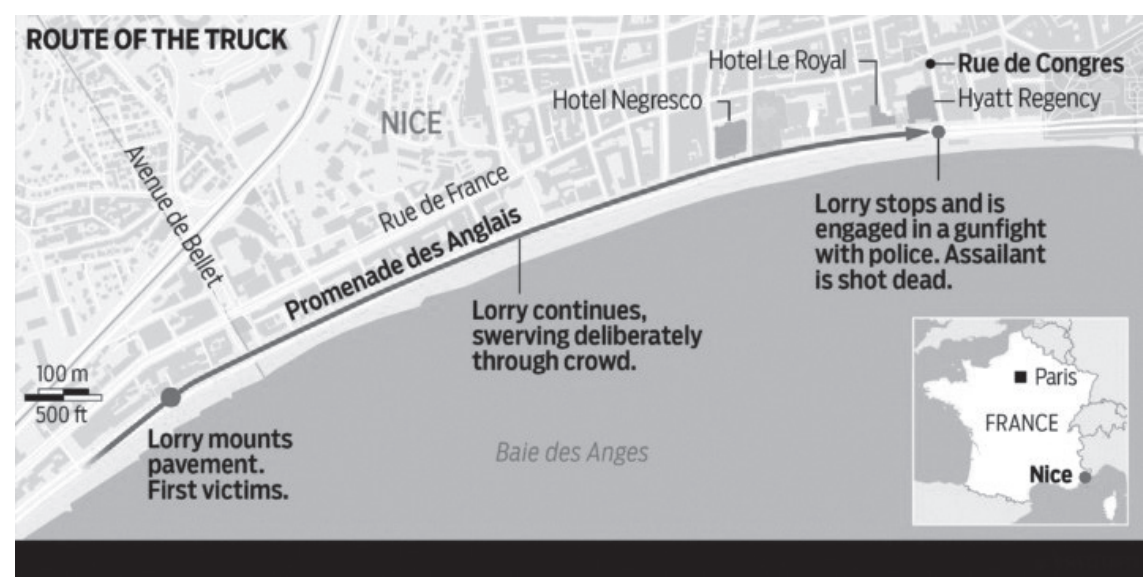

Picture 3. The scene of the tragedy in Nice. [21]

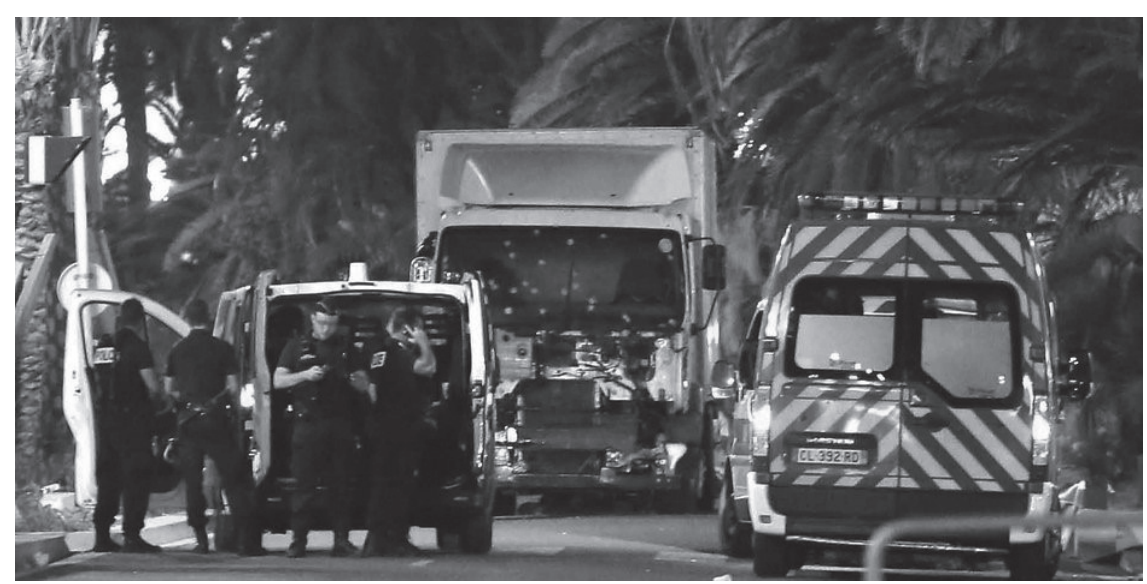

Picture 4. Police and Ambulance at the site of the tragedy in Nice. [22]

The attacker was a man of Tunisian origin from Nice who was shot by the police. It is still unknown whether he had any allies. A large amount of ammunition and weapons were found in the vehicle he drove, on the plateau of the truck.

The secondary consequence of such attacks is that the panicking people fleeing the location can get injured. The situation is well described by the fact that a temporary hospital had to be established. Taking into consideration the lessons of the incident, the German police has already secured the carnival in Cologne with armoured vehicles that can serve as sufficient mobile road blocks due to their size and weight. These vehicles mostly work as a deterrent and by collision they can also change the movement direction of heavy vehicles. 


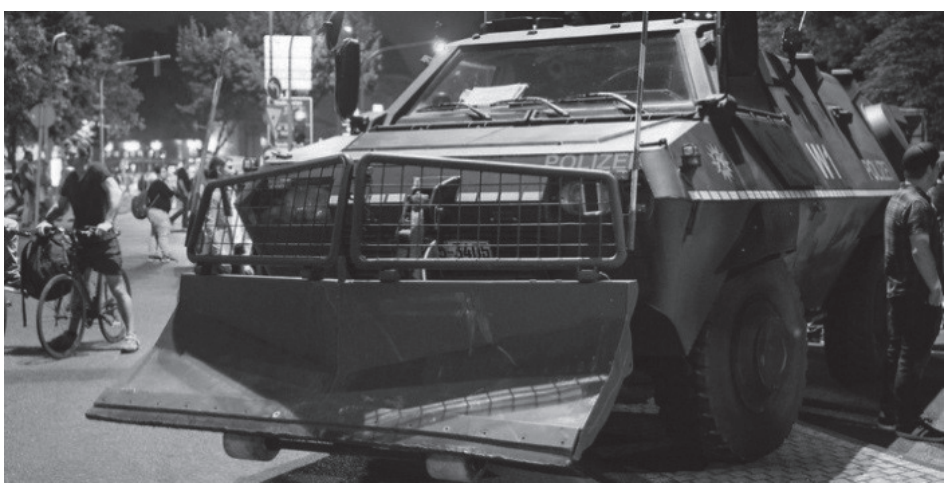

Picture 5. The armoured vehicle of the police in Cologne. [23]

\section{Protection Requirements in Light of the Threat}

Taking into consideration the introduced dangers wilfully caused by humans, the forces carrying out law enforcement activities as well as public service tasks need to face the following problems:

- high possibility of weapon usage in case of terrorist activities;

- possibility of manufacturing large number of explosives in a short time period, but more importantly in a barely or non-traceable way;

- terrorists mostly focusing on the end result of their activities, while protecting their own physical integrity or life is inferior to the purpose of their actions;

- attacks that can also be carried out by European residents;

- riskiness for official personnel to approach areas of questionable safety by vehicles without proper reconnaissance information;

- possibility of rifle and assault rifle usage, therefore preparation for utilization of weapons of increased fire power as well as armour-piercing ammunition even from a few hundred meters distance is required.

The protection requirements in this case target the effects caused by weapons and explosives. Taking into account the wave of migrants commencing from the Near East or Africa and going through the Balkan states or Southern Europe, the possibility of having larger calibre or even armour-piercing weapons transported to Europe from the areas affected by armed conflicts needs to be considered.

\section{Requirements for the Applicable Protected Vehicles}

The protection of the personnel executing public service tasks could be remarkably increased by using special protected vehicles. For the selection of proper vehicles, the required characteristics need to be summarized: 
- strong off-road and obstacle-conquering capability, i.e. stairs or roadsides at inhabited areas should not mean any obstacle;

- the ability to maintain the capacity to move is also important, i.e. the vehicle should be able to change its position and move forward even with damaged tires;

- capability of quickly changing its position, but high-speed change of direction is not required - quick response and no vehicle for hunting is needed if establishing a road block is required;

- it can serve as a shelter against weapon fire;

- it can serve as a shelter against explosion and fragmentation effect;

- due to its protective capacities it can be used for rescuing injured individuals;

- it needs to be able to operate without outside assistance and without endangering others on the road.

\section{The Possibilities of Using Protected Vehicles}

Using a Mine Resistant Ambush Protected (MRAP) vehicle might seem obvious for securing the location at endangered areas or areas struck by a terror attack or disaster.
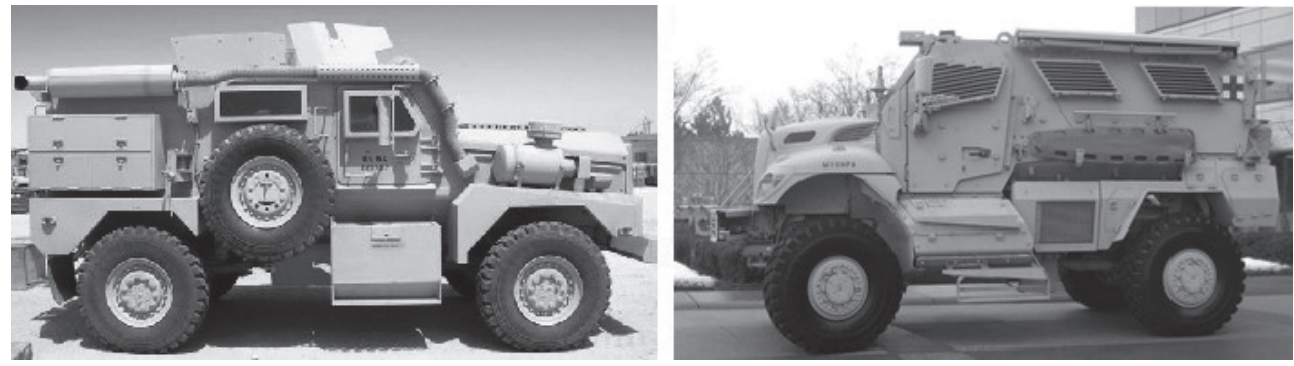

Picture 6. Navistar Maxxpro and Force Protection Cougar type MRAP vehicles. [24] [25]

The MRAP [26] vehicles have been used by the United Stated Armed Forces since 2004 as part of an experimental training; the MRAP program was launched in 2006. The category I and II MRAP vehicles had to meet well-considered criteria matching the combat application. In a civil environment the following criteria are the most important: [26]

- forward speed of at least $100 \mathrm{~km} / \mathrm{h}$ on a paved surface with a $0 \%$ gradient;

- off-road speed of at least $7 \mathrm{~km} / \mathrm{h}$;

- $40 \mathrm{~km} / \mathrm{h}$ speed on dirt-road;

- minimum speed of $10 \mathrm{~km} / \mathrm{h}$ when conquering a dirt-road surface with a $40 \%$ gradient;

- no malfunction within 170 hours of operational time based on an average of 18-hour usage per day, which means 10 days of continuous use without any failures;

- transportability of the vehicle by rail, marine, and air as well as on all main roads and highways individually or as part of a convoy;

- all tires need to have a run flat capability in case of any tire damage;

- $50 \mathrm{~km} / \mathrm{h}$ speed on a paved surface even if two tires are damaged;

- diesel engines capable of functioning in all environmental conditions. 
The military usage also requires the following attributes, but these are not of high importance in a civilian environment:

- capability to fill the vehicle with fuel sufficient for driving $480 \mathrm{~km}$ on a paved surface with an average speed of $70 \mathrm{~km} / \mathrm{h}$;

- no failures should arise when driving no less than an average of $1930 \mathrm{~km}$;

- capability of being transported by C-17, C-5, C-130 aircrafts;

- preparation for fixed wing air transport, and follow-up reassembly to be accomplished in not more than 60 minutes.

The most important requirements were related to increasing the safety of the soldiers, but they can also mean the protection of the personnel carrying out public service tasks:

- capability of the armour to protect the personnel travelling in the vehicle from explosions, fragments and other effects arising from the vehicle falling over due to the explosion;

- the STANAG 4569 [27] contains the number of explosives matching the protection levels; ${ }^{3}$

- capability of the armour plate below the interior area to resist explosions happening under the vehicle and to protect the personnel from fatal injuries.

Furthermore, the MRAP vehicles are capable of:

- climbing surfaces with a $60 \%$ gradient;

- conquering vertical barriers of $36 \mathrm{~cm}$ (vertical step);

- moving in 90-95 cm deep water without any preparations required (fording).

An MRAP vehicle is capable of carrying out the following tasks:

- securing an area;

- presence;

- patrol activities;

- providing protection for the personnel executing public service tasks;

- Pursuit Intervention Technique against another vehicle;

- approaching areas with risk of explosion.

Maintaining mobility is highly important for the usability and applicability of these vehicles. Using run-flat tires is recommended for heavy vehicles, especially for protected vehicles. Tires equipped with a support ring make it possible for the vehicle to drive at 50 $\mathrm{km} / \mathrm{h}$ for another $80 \mathrm{~km}$.

Test and evaluation methods are described in the AEP 55 Vol. 1 [28] 

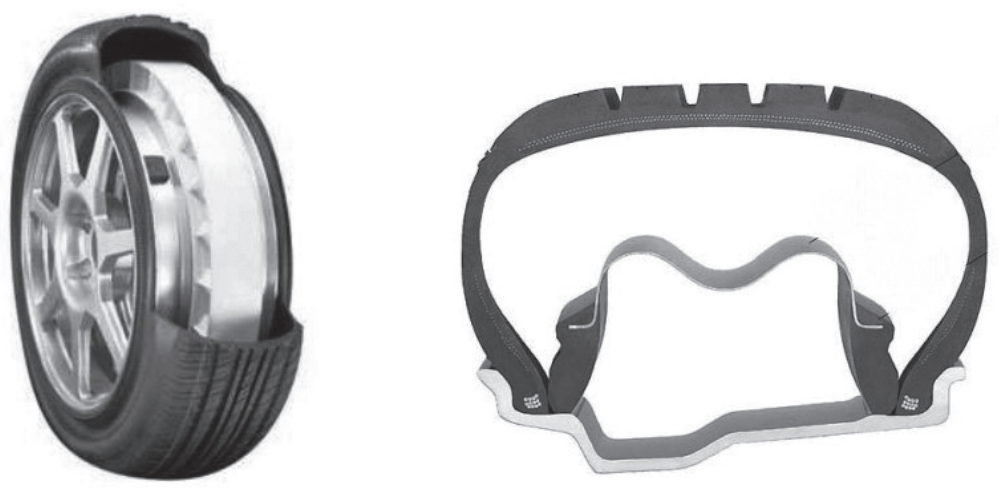

Picture 8. Run-flat tire with support ring. [29]

\section{Protected Vehicles of MRAP Category Already Used by Disaster Management}

Using MRAP vehicles for public service tasks has already started and the experiences are being gathered.

The Law Enforcement Support Office had 196 MRAP vehicles transferred to different law enforcement agencies until August 2013. As many as 780 agencies have expressed their intention for using the vehicles.

The requesting agencies wish to react to arising needs such as the specific requirements of armed conflicts, anti-drug and SWAT missions. The requesters were aware of the special maintenance needs and rather high costs of the vehicles. [30]

At the time of the MRAP program closure approximately 25,000 appliances were available. These vehicles have definitely saved some 4,000 lives, since they provided protection against ambushes committed with weapons or bombs that became an everyday threat.

In the Unites States the decrease in the number of MRAP category vehicles was caused by the regulation of the Armed Forces budget and the increase in the equipment value. [31] However useful they had proved to be previously, the Pentagon wanted to discard several thousand MRAPs. It was stated at the meeting of the Senate Committee on Armed Services in March 2014 that it is cheaper to destruct the vehicles at their location of application (US $\$ 10,000)$ or to donate them to allies in the region than to transfer them to the United States (US \$50,000).

The cost of the devices during their in-service time is hard to estimate, but it became obvious that based on the decision of the US Government the aim is to use these vehicles that became a burden in the most optimal way. The urge to decrease the costs has shown an interesting field of application in case of armoured vehicles.

Homeland Security Investigation (HSI) New Orleans is one of the first ones to be equipped with a Mine Resistant Ambush Protected Vehicle. [32] The objectives of the application of the new devices were the following:

- rapid deployment during natural and manmade disasters; 
- providing immediate support for the Immigration and Customs Enforcement (ICE) in case of emergency situations.

Weighing 16 tons and approximately 3 meters tall, this heavy-duty vehicle was well suited for emergency high-water rescue operations in New Orleans during the disaster. [33]

The weather conditions made even more difficult the rescue activities; an approximately five hours of rainfall and storm surge, as well as the flood waters that rose above a safe operating level considerably hindered the operation.

In one of the cases, the Special Response Team and Rapid Response Team were able to jump into action within minutes of receiving the request and forging through the waterlogged streets managed to rescue 12 individuals. Since then the team is operational 24 hours a day, seven days a week and is always prepared to deploy to an affected area within 12 to 24 hours.

Special armoured vehicles have already been used in a special situation as well, where a SWAT unit broke into a house in Phoenix, since a man had barricaded himself and shot at the arriving police officers. [34]

\section{Conditions of Using Protected Vehicles}

When examining the usage of a new vehicle, the following requirements always need to be determined:

- Which organization is operating the device? ${ }^{4}$

- Which organization is planning the operational and maintenance costs?

- Which organization provides the trained driver and operating staff?

- If required, how and under which circumstances will the vehicle arrive at the location? Is it allowed to operate individually, without escort or route licence?

- Where should the device be based?

Due to their extent, operation and maintenance are not discussed in detail in this research, these require further examinations. The already mentioned disaster management usage can serve as a basis for clarifying the operating organization. The human resource need and its feasibility also need to be clarified henceforward, but the training of the operation staff is possible. [35] Training and maintaining the qualification level is necessary, as unfortunately an accident has already happened in the US that was caused by an untrained and unlicensed driver. The root cause of the accident was a tire blowout that made the driver lose control over the vehicle. The accident could have been avoided with proper driver experience, as it is possible to keep going also with injured run-flat tires. In such cases it is especially useful if the driver is notified of the pressure shrinkage in the tires. [36]

$4 \quad$ The BTR-80 fighting vehicles used by the Counter Terrorism Centre are the property of the Hungarian Defence Forces. 


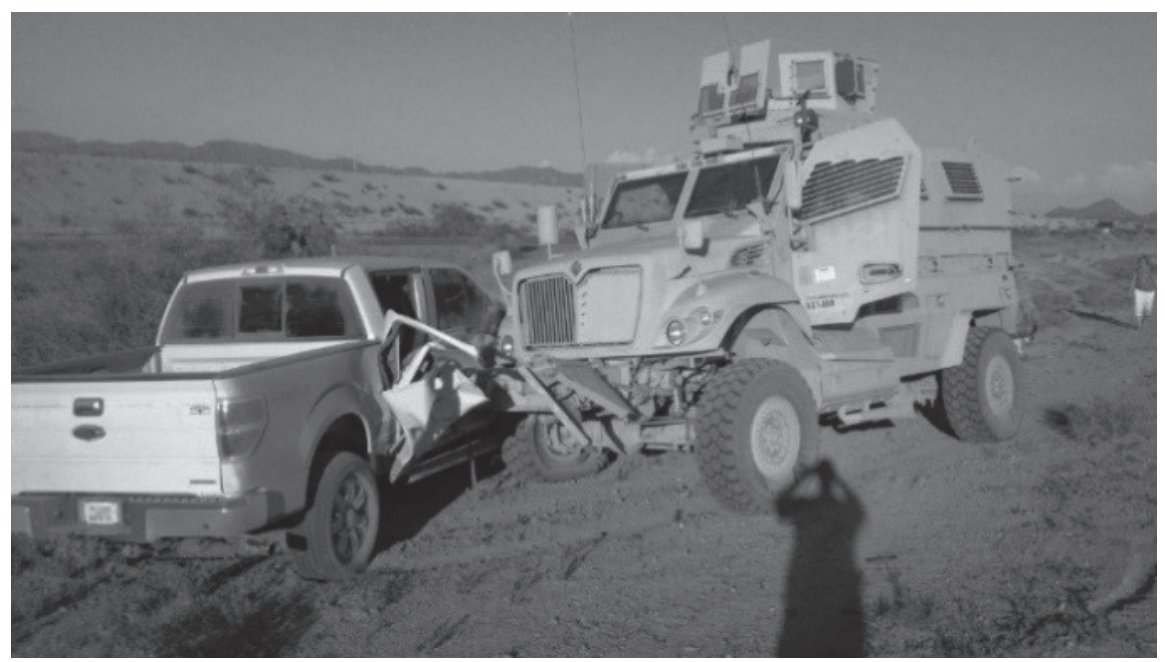

Picture 9. Accident caused by an inexperienced police officer with an MRAP vehicle. [35]

In Hungary the conditions of road usage need to be taken into consideration when applying the vehicles. Decree Nr. 36/2017. (IX. 18.) issued by the Ministry of National Development contains the data applicable to vehicles equipped with tires. "The material scope of the regulation comprises the transport of vehicles and combinations of vehicles exceeding the allowed total mass, axle load, tandem axle (axle group) load and size (hereinafter referred to as overweight or oversized vehicles) on national roads, on local roads and by state or local government owned not enclosed private roads.” [37] Based on the decree, if an MRAP category vehicle meets the requirements of Table 1, it is allowed to use the road network of Hungary without a route licence.

Table 1. Technical specification of vehicles subject to route licence. [Edited by the author.]

\begin{tabular}{|l|l|l|r|}
\hline \multirow{3}{*}{ Axle load } & $\begin{array}{l}\text { Two axles vehicles (MRAP } \\
\text { category I.) }\end{array}$ & Non-driven axle & $11.5 \mathrm{t}$ \\
\cline { 2 - 4 } & \multicolumn{2}{|l|}{ Axle } & $>20 \mathrm{t}$ \\
\cline { 2 - 4 } & $\begin{array}{l}\text { Three axles vehicles (MRAP } \\
\text { category II.) with tandem axle }\end{array}$ & $\begin{array}{l}\text { Any axle, or tandem axle, if the dis- } \\
\text { tance between the axles is not larger } \\
\text { than } 1.00 \mathrm{~m}\end{array}$ & $11.5 \mathrm{t}$ \\
\hline Width & $2.6 \mathrm{~m}$ \\
\hline Height & $4 \mathrm{~m}$ \\
\hline Length & $12 \mathrm{~m}$ \\
\hline
\end{tabular}

5 Although the requirements are stated in the text of the regulation, yet every axle of an MRAP vehicle is driven. 
Granting approval for the transport of overweight or oversized vehicles is done by the Military National Security Service or in case of the transport of vehicles operated by the Hungarian Defence Forces or by others operating on behalf of the Hungarian Defence Forces, the organization outlined in the ministerial decree on vehicles exceeding the allowed total mass, axle load, tandem axle (axle group) load and size is the authorized approver. The Hungarian Public Road Non-profit Plc has jurisdiction in case the vehicle is operated by another organization and the expected routes cross several administrative territories owned by the local government.

Table 2. Technical specifications of MRAP vehicles. [Edited by the author.]

\begin{tabular}{|c|c|c|c|c|}
\hline $\begin{array}{ll}\text { Technical } \\
\text { specifications }\end{array}$ & $\begin{array}{c}\text { Oshkosh MRAP } \\
(\mathrm{M}-\mathrm{ATV})^{6} \\
{[38][39][40]}\end{array}$ & $\begin{array}{l}\text { Cougar } \\
\quad 6 \times 6 \\
{[41][42][43]}\end{array}$ & $\begin{array}{c}\text { Cougar } \\
4 \times 4 \\
{[43][44]}\end{array}$ & $\begin{array}{l}\text { Maxxpro } \\
{[45][46]}\end{array}$ \\
\hline Seating (person) & $4+1(7)$ & $2+8$ & $2+4$ & $2+4(8)$ \\
\hline Maximum road speed $(\mathrm{km} / \mathrm{h})$ & 104 & 104 & 105 & 105 \\
\hline Gross weight (kg) & 2,000 & 29,257 & 19,504 & 18,650 \\
\hline Payload (kg) & 1,814 & n.a. & 4,000 & 1,655 \\
\hline $\begin{array}{l}\text { Length/ } \\
\text { Width/ } \\
\text { Height (m) }\end{array}$ & $\begin{array}{l}\text { n.a. } \\
\text { n.a. } \\
\text { n.a. }\end{array}$ & $\begin{array}{l}7.0 \\
2.6 \\
2.64 \\
\end{array}$ & $\begin{array}{l}6.35 \\
2.71 \\
3.02 \\
\end{array}$ & $\begin{array}{c}6.0-6.7 \\
2.51 \\
2.92 \\
\end{array}$ \\
\hline $\begin{array}{l}\text { Number of doors } \\
\text { (side, rear, on the roof) }\end{array}$ & $2(4)+1(0)+1$ & $2+1+1$ & $2+1+1$ & $2+1+1$ \\
\hline Range (km) & 512 & $512 / 670$ & 672 & 600 \\
\hline $\begin{array}{l}\text { Military } \\
\text { operations }\end{array}$ & \multicolumn{4}{|c|}{$\begin{array}{l}\text { MEDEVAC, }{ }^{7} \text { reconnaissance, convoy support, other } \\
\text { special tasks }\end{array}$} \\
\hline Trench (m) & 0.5 & 0.5 & 0.5 & 0.5 \\
\hline Vertical step (m) & 0.5 & 0.5 & 0.5 & 0.6 \\
\hline Fording (m) & 0.9 & \multicolumn{2}{|c|}{$0.736 / 1.00$} & 0.91 \\
\hline Gradient & $60 \%$ & & $60 \%$ & $70 \%$ \\
\hline Side slope & $40 \%$ & & $30 \%$ & $30 \%$ \\
\hline
\end{tabular}

\section{Equipment Selection and Procurement}

The introduced vehicle specifications suggest that response options are available for the defence requirements outlined in the publication, but this is not sufficient in itself. Assigning to each other equipment or tasks that were introduced as examples requires a very detailed analysis. [47] All conditions of the vehicle usage need to be taken into consideration. [48] Procurement of these vehicles is rather expensive, the equipment acquirable from abroad also cost US \$600,000-1,000,000 even in a used state. 

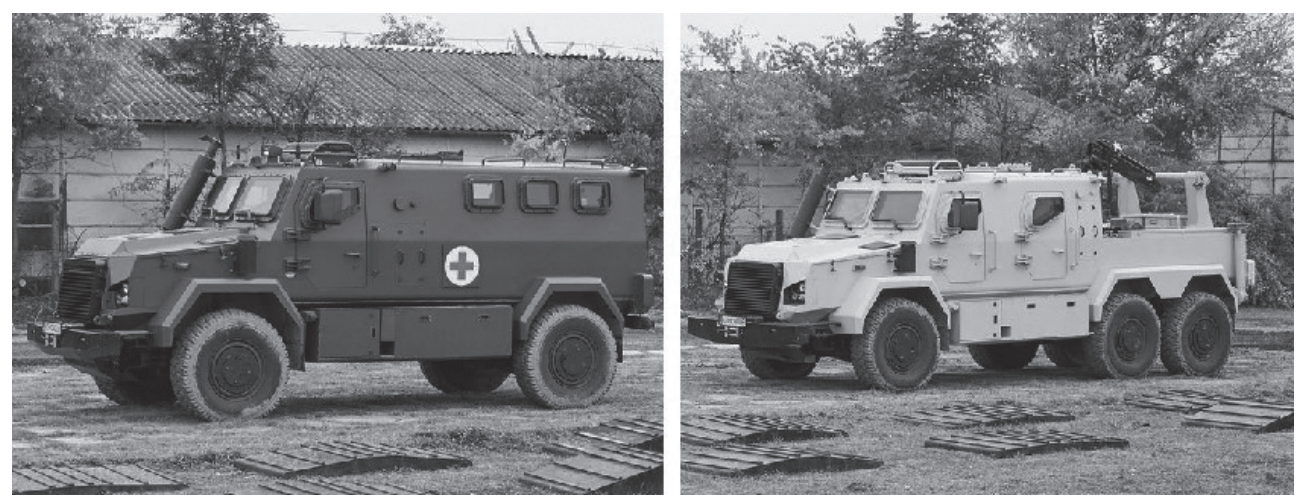

Picture 10. Two separately configured vehicles from the Komondor family. [49]

The Hungarian military industry is already capable of producing vehicles of such protection levels by ordering and purchasing the parts and components from vendors who are in connection with Hungary and are executing their production activities here. [50] [51] The product range of Respirátor Ltd. contains differently configured vehicles as part of the Komondor family. The aim of the first vehicle improvement was the creation of an equipment capable of NBC reconnaissance. [52]

\section{Conclusion}

Based on the introduced scenarios and possible threats a vehicle with appropriate protective, off road, barrier conquering and mobility sustaining capabilities is required in case of disasters or terror attack prevention activities, apart from which it could also be effectively used for law enforcement tasks as a road block or shelter. If the turret has not been installed or has been removed, a neutral coloured MRAP vehicle rather looks like a truck. This means that it will not be regarded negatively by the civilians on the streets, while an armoured combat vehicle causes mixed feelings in the population. The presence of the vehicle at a crowded event undoubtedly signals the preparedness of the law enforcement forces and this can have a deterrent power, as well.

There are vehicles that are suitable for this task and can be used on public roads, as well. Appropriate methods exist for optimizing the procurement results and if required, the Hungarian military industry is capable of producing the equipment with the desired protection capabilities.

The questions concerning requirement and feasibility need a detailed analysis and the possibility of establishing new organizational units or organizations dealing with the equipment need to be investigated. 


\section{References}

[1] CZÉKMANN Z.: A közszolgálat és a közigazgatás személyzeti rendszere. http://jogikar.unimiskolc.hu/projectSetup/files/koi/kozig1/a-kozszolgalat.pdf (Downloaded: 05.06.2017)

[2] CSIKÁSZ B.: Mire kell a harci jármú a TEK-nek? HVG (online), 2012. 08. 29. http://hvg.hu/itthon/20120827_Felelmet_keltenek_majd_a_TEK_harci_jarmuv (Downloaded: 07.06.2017)

[3] FERWAGNER P. Á., KORMÁR K., SZÉLINGER B.: Terrorista szervezetek lexikona. Szeged: Maxim Könyvkiadó, 2003.

[4] POKKER Z., BARKÓCZI E., CSEFFÓ K.: Belügyi-rendészeti Ismeretek II. Budapest: Országos Rendészeti TISZK, 2011. www.koskarolyszki.hu/file/133/tk_2.pdf (Downloaded: 07.06.2017)

[5] 11/1998. (IV. 23.) ORFK utasítás a Magyar Köztársaság Rendőrségének Csapatszolgálati Szabályzata kiadásáról.

[6] EISEMANN K., GYURNIK M., BOZÁNÉ TÖRÖK E., RANGA A., VÖRÖS E.: Jogi ismeret jegyzet a büntetés-végrehajtási szervező és felügyelő szakképzéshez. Budapest: Büntetés-végrehajtási Szervezet, 2017. http://bv.gov.hu/download/8/fd/b1000/ JOGI\%20ISMERETEK\%20-\%20JEGYZET\%202017.pdf (Downloaded: 10.07.2017)

[7] 5/2006. (II. 7.) EüM rendelet a mentésröl.

[8] Kinek mi a feladata a mentőben? Budapest: OMSZ, s.d. www.human.eoldal.hu/cikkek/ feladat.html (Downloaded: 10.08.2017)

[9] Iparbiztonság - Bemutatkozás. Budapest: BM OKF, s.d. www.katasztrofavedelem.hu/ index2.php?pageid=iparbiztonsag_index (Downloaded: 10.08.2017)

[10] LYNCH, D.: Charlie Hebdo Massacre: Illegal Gun Trafficking Brings Millions of Weapons into the EU. International Business Times (online), 01.09.2015. www.ibtimes.com/ charlie-hebdo-massacre-illegal-gun-trafficking-brings-millions-weapons-eu-1779070 (Downloaded: 10.08.2017)

[11] LEVS, J., PAYNE, E., PEARSON, M.: A timeline of the Charlie Hebdo terror attack. CNN (online), 08.01.2015. http://edition.cnn.com/2015/01/08/europe/charlie-hebdo-attacktimeline/index.html (Downloaded: 10.08.2017)

[12] EPRESI J.: Kettős merénylet Norvégia ellen. Kitekintő (online), 2011. 07. 25. http:// kitekinto.hu/europa/2011/07/25/ketts_merenylet_norvegia_ellen (Downloaded: 10.08.2017)

[13] EDMONDSON, N.: Anders Behring Breivik Trial: Norse God Thor and Odin Engravings on Killer's Guns. International Business Times (online), 02.07.2014. www.ibtimes.co.uk/ anders-behring-breivik-thor-odin-guns-police-336683 (Downloaded: 10.08.2017)

[14] Képek az oslói robbantás helyszínéről. HVG (online), 2011. 07. 22. http://hvg.hu/ nagyitas/20110722_pokolgep_robbant_osloban (Downloaded: 10.08.2017)

[15] Norvégia: eredménytelen rendőri akció. HVG (online), 2011. 07. 24. http://hvg.hu/ vilag/20110724_norvegia_robbantas_meszarlas (Downloaded: 10.08.2017)

[16] McNAB, Ch.: Az AK-47-es. (Magyar kiadás). Debrecen: Hajja és Fia Kiadó, 2002.

[17] MTI: A NATO beavatkozása hozta el a délszláv háború végét. Múlt Kor (online), 2015. 08. 30. http://mult-kor.hu/a-nato-beavatkozasa-hozta-el-a-delszlav-haboru-veget-20150830 (Downloaded: 15.08.2017) 
[18] MTI: Rémisztő: fegyverek tűntek el egy katonai raktárból. Népszava (online), 2016. 11. 17. http://nepszava.hu/cikk/1112198-eltuntek-a-fegyverek-egy-katonai-raktarbol (Downloaded: 10.08.2017)

[19] Ünneplő tömegbe hajtott egy teherautó Nizzában, sokan meghaltak. Híradó (online), 2016. 07. 15. www.hirado.hu/2016/07/15/unneplo-tomegbe-hajtott-egy-teherauto-nizzaban-sokanmeghaltak (Downloaded: 21.06.2017)

[20] A Trail of Terror in Nice, Block by Block. New York Times (online), 14.07.2016. www.nytimes.com/interactive/2016/07/14/world/europe/trail-of-terror-france.html (Downloaded: 21.06.2017)

[21] VINOCUR, N., DALLISON, P., SHEFTALOVICH, Z.: At least 84 dead after truck hits crowd in Nice. President Hollande calls Bastille Day attack "terrorism”. Politico (online), 15.07.2016. www.politico.eu/article/dozens-killed-as-truck-drives-into-bastille-day-crowdin-nice-reports/) (Downloaded: 10.08.2017)

[22] CHAZAN, D.: Nice killer "made 12 reconnaissance trips in illegal lorry” without being turned back. The Telegraph News (online), 23.07.2016. www.telegraph.co.uk/ news/2016/07/23/nice-killer-made-12-reconnaissance-trips-in-illegal-lorry-withou/ (Downloaded: 12.08.2017)

[23] ESCH, S.: Karneval in Köln Polizei plant Straßensperrungen als Schutz vor Angriffen mit LKW. Kölner Stadt-Anzeiger (online), 25.01.2017. www.ksta.de/koeln/karnevalin-koeln-polizei-plant-strassensperrungen-als-schutz-vor-angriffen-mit-lkw-25611472 (Downloaded: 12.08.2017)

[24] Navistar's MaxxPro: $1^{\text {st }}$ Place in MRAP Orders. Defense Industry Daily (online), 13.03.2017. www.defenseindustrydaily.com/more-mraps-1200-maxxpro-mpvs-fromnavistar-03344/ (Downloaded: 12.09.2017)

[25] Cougar Ridgback $4 \times 4$ MRAP Armoured Vehicle. Army Technology (online), s.d. www.army-technology.com/projects/cougar_ridgback/ (Downloaded: 12.08.2017)

[26] Mine Resistant Ambush Protected (MRAP) Vehicle Program. GlobalSecurity (online), s.d. www.globalsecurity.org/military/systems/ground/mrap-req.htm) (Downloaded: 12.08.2017)

[27] STANAG 4569 (EDITION 2) - Protection levels for occupant of armoured vehicles. www. unops.org/Apply BO/File.aspx/4569eed02.pdf?AttachmentID=52d5a7b6-37ad-49bc-b18cc468ea81787a (Downloaded: 12.09.2017)

[28] Procedures for evaluating the protection level of logistic and light armoured vehicles. Volume 1. Kinetic energy and artillery threat. AEP 55, NATO Standardization Agency February, 2005

[29] VÉG R.: Defekttűrő és defektmentes gumiabroncsok. Bolyai Szemle, 212 (2012), 173-184.

[30] PARSONS, D.: Repurposed MRAPs Find New Life in Police Agencies. National Defense (online), 04.01.2014. www.nationaldefensemagazine.org/articles/2014/4/1/2014aprilrepurposed-mraps-find-new-life-in-police-agencies (Downloaded: 12.08.2017)

[31] McGARRY, B.: Corps to Industry: Prepare for the Worst. Military.com, 26.09.2013. http://www.dodbuzz.com/2013/09/26/corps-to-industry-prepare-for-the-worst / (Downloaded: 12.08.2017)

[32] HSI Rapid Response Team saves 14 stranded by Hurricane Isaac. Department of Homeland Security (online), 09.06.2012. www.ice.gov/news/releases/top-story-hsi-rapid-responseteam-saves-14-stranded-hurricane-isaac (Downloaded: 12.09.2017) 
[33] Hostages freed in Phoenix barricade situation; 3-year-old Israel Celis found safe. abc15 Arizona (online), 20.05.2013. www.abc15.com/news/region-west-valley/tolleson/amberalert-3-year-old-missing-from-tolleson (Downloaded: 12.09.2017)

[34] SWAT team smashes into Phoenix home where child-abduction suspect is located. abc15 Arizona (online), s.d. www.abc15.com/news/news-photo-gallery/swat-team-smashes-intotolleson-home-where-child-abduction-suspect-is-located\#id6 (Downloaded: 12.09.2017)

[35] Unlicensed banning police officer speeds, crashes armoured military combat vehicle. www.thebanninginformer.com/?page_id=7178 (Downloaded: 12.09.2017)

[36] VÉG R., PALKOVICS A.: Gumiabroncs nyomásellenőrzése. Bolyai Szemle, 1 (2013), 25-34. http://archiv.uni-nke.hu/downloads/bsz/bszemle2013/1/02.pdf (Downloaded: 12.09.2017)

[37] 36/2017. (IX. 18.) NFM rendelet a meghatározott össztömeget, tengelyterhelést, tengelycsoport-terhelést és méretet meghaladó járművek közlekedéséről. https://net.jogtar.hu/jr/gen/ hjegy_doc.cgi?docid=A1700036.NFM) (Downloaded: 12.09.2017)

[38] M-ATV. Military.com, s.d. www.military.com/equipment/m-atv (Downloaded: 12.09.2017)

[39] Bring protected speed, mobility and versatility to offensive operations. Oshkosh Defense (online), s.d. https://oshkoshdefense.com/variants/assault/ (Downloaded: 12.09.2017)

[40] GENYS, A.: Oshkosh M-ATV Mine resistant ambush protected vehicle. Military Today (online), s.d. www.military-today.com/apc/oshkosh_matv.htm (Downloaded: 12.09.2017)

[41] Cougar $6 \times 6$ MRAP. www.military.com/equipment/cougar-6x6-mrap (Downloaded: 12.09.2017)

[42] GENYS, A.: Cougar Mine resistant ambush protected vehicle. Military Today (online), s.d. www.military-today.com/apc/cougar_mrap.htm (Downloaded: 12.09.2017)

[43] The Cougar has spawned into a new line of all-important mine-resistant vehicles for the US and British military forces in Iraq. Military Factory (online), 29.12.2017. www. militaryfactory.com/armor/detail.asp?armor_id=291 (Downloaded: 30.12.2017)

[44] Cougar $4 \times 4$ MRAP. www.military.com/equipment/cougar-4x4-mrap (Downloaded: 12.09.2017)

[45] GENYS, A.: MaxxPro Mine resistant ambush protected vehicle. Military Today (online), s.d. www.military-today.com/apc/maxxpro_mrap.htm (Downloaded: 12.09.2017)

[46] Specifications MaxxPro. GlobalSecurity (online), s.d. www.globalsecurity.org/military/ systems/ground/maxxpro-specs.htm (Downloaded: 12.09.2017)

[47] GYARMATI J.: Döntési modell kialakítása közbeszerzési eljárás során. Hadmérnök, 23 (2007), 36-52. http://hadmernok.hu/archivum/2007/3/2007_3_gyarmati.pdf (Downloaded: 12.09.2017)

[48] GYARMATI J.: Többszempontos döntéselmélet alkalmazása a haditechnikai eszközök összehasonlításában. (PhD-értekezés) Budapest: ZMNE, 2003. http://m.ludita.uni-nke.hu/ repozitorium/bitstream/handle/11410/9677/Teljes\%20szöveg.?sequence=1\&isAllowed=y (Downloaded: 12.09.2017)

[49] RESPIRÁTOR: RDO-3221 Komondor galéria. http://respirator.hu/img/komondor_ photogalery/index.php (Downloaded: 12.09.2017)

[50] RESPIRÁTOR: RDO-322 Komondor Ligh Armoured Vehicle. www. respirator.hu/?mnuGrp=\&module=products\&lang=hun\&group=sajat_ katonaiharcjarmu\&product=rdo-3231_komondor\&termek=RDO-3221\%20 KOMONDOR\%20Light\%20 Armoured\%20Vehicle\%20\&menupath=sajat_ 
GY. GÁVAY: Military Vehicles Used for Public Service Purposes

katonaiharcjarmu\&csoport=Katonai\%20harcj\%C3\%A1rm\%C5\%B1vek\%20\%C3\%A9s\%20 ut\%C3\%A1nfut\%C3\%B3k (Downloaded: 12.09.2017)

[51] BALOGH B. J.: Gőzerővel folyik az új Komondor harcjármúvek üzemi vizsgálata.

Biztonságpiac (online), 2014. 09. 08. http://biztonsagpiac.hu/gozerovel-folyik-az-ujkomondor-harcjarmuvek-uzemi-vizsgalata (Downloaded: 12.09.2017)

[52] GAMMATECH: Hazai gyártású páncélozott ABV felderítő jármű. http://gammatech.hu/ komondor/ (Downloaded: 12.09.2017) 